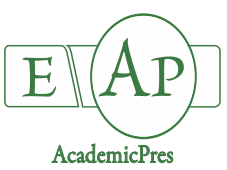

Notulae Botanicae Horti Agrobotanici Cluj-Napoca
DOI: $10.15835 /$ nbha48411929
Research Article

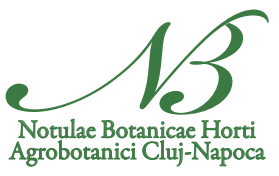

\title{
Effects of biological fertilizers and sulfur on the quantitative and qualitative traits of cultivated shallot (Allium altissimum Regal) and comparison of these traits with those ones in the natural habitat
}

\author{
Ebrahim KAKOLVAND ${ }^{1}$, Khosro AZIZI ${ }^{1 *}$, Ahmad ESMAILI ${ }^{1}$, \\ Mohsen ADELI ${ }^{2}$ \\ ${ }^{1}$ Department of Agronomy, Faculty of Agriculture and Natural Resources, Lorestan University, Iran; Kakolvand.eb@fa.lu.ac.ir;
azizi.kh@lu.ac.ir (" ${ }^{*}$ corresponding author); ismaili.a@lu.ac.ir
${ }^{2}$ Department of Chemistry, Faculty of Basic Sciences, Lorestan University, Khorramabad, Iran; mohadeli@yahoo.com
}

\begin{abstract}
The present study was conducted aiming at the protection of the shallot (Allium altissimum Regal) in natural habitat, which is endangered due to excessive harvesting. In order to increase the sustainability of this product, its wild ecotypes were planted in agricultural land and the effect of bio-fertilizers (nitroxin and phosphate) and sulfur on quantitative (yield and yield components) and qualitative (the active ingredient, allicin, crude protein, and the amount of phosphorus and potassium) traits were investigated. The results showed that the amount of allicin, crude protein, phosphorus, potassium, and yield in the planted ecotypes were significantly higher than the wild type in the studied natural habitat. The results of this study indicated a significant difference respecting quantitative and qualitative trait of cultivated shallot with proper nutritional management compared to wild shallot. Therefore, the expansion and development of this method can lead to the sustainability of the production of shallot and will conserve diversity of its populations in natural habitat.
\end{abstract}

Keywords: medicinal and aromatic plant; nutritional treatment; plant biodiversity; sustainability; wild harvesting

\section{Introduction}

The global food demand increases the need for the increasing use of natural resources such as water, land, and nutrients for producing the crops (Tilman et al., 2011). To this end, three major pathways are identified, including decreasing the loss of agro-ecological production capacity and the demand for food, and increasing food production (Dogliotti et al., 2014). The growth of global food production requires increasing the use of chemical fertilizers although the current environmental impact of agricultural fertilizer consumption has reached its planetary boundaries (Steffen et al., 2015).

Sustainable development of agriculture has always been an important task for us to monitor the longterm changes in soil quality and uncover their hidden rules (Huang et al., 2015). Considering the growing need for medicinal and industrial plants that can be harvested from natural habitats, as well as the increasing degradation of their natural habitats, the crop production of these species in agricultural systems can act as an 
important strategy in supplying the growing market of these plants (Uniyal et al., 2001). The content of raw fats and aromatic vegetable oils depends on the method of plant production (Gitin et al., 2012). Previous studies indicate that the total amount of phenol, organo sulfur compounds, and antioxidant activities in different shallot species rely on biological factors and environmental conditions (Beato et al., 2010).

Pharmaceutical and industrial cultivation and production of plants are not only a means of meeting the growing needs of present and future pharmaceutical compounds but also an approach for reducing the pressure on plant communities in natural areas (Bodeker, 2002). Shallot (Allium altissimum Regal) is one of the most important medicinal plants of the Alliaceae family that grows naturally in regions with cold to semi-cold climates, including Lorestan, Khorasan, and other areas of Iran with an altitude of more than $1000 \mathrm{~m}$ above the sea level (Kheyrkhah, 2009).

This plant has cylindrical and hollow leaves that reach about $30 \mathrm{~cm}$ in length. In addition, the shallot is reproduced through planting maternal onions and its most important constituents are disulfide and trisulfide. Its underground stem is widely used in traditional medicine and pharmaceutical industries (Channagoudar et al., 2006). Microvessel colonization can play a significant role in the growth and intensification of garlic plants, and the effects of fungal colonization can be related to fungal isolates. While the appropriate fungal species Glomus fasciculatum helps to increase yield and control the intensity of taste for consumers. In addition, the promotion of microscopic colonization of muscle fungi has the advantage of reducing nutrient inputs to the environment (Borde et al., 2009). Furthermore, its therapeutic effects include treating rheumatism, surface ulcer healing, and kidney stones, as well as decreasing the blood pressure, having anti-diarrhea, antimicrobial, and appetizing properties, and strengthening the digestive system. Moreover, the extract of the shallot bulb inhibits cancer cell proliferation (Amin et al., 2001). The use of bio-fertilizers prevents environmental pollution while improving the mass production of plants. Consequently, the industrial production of biofertilizers or their mixtures has received considerable attention. These products are utilized to stimulate plant growth and increase yield (Fang Sheng et al., 2006). Kopriva et al. (2002) reported a biological relationship of some plants, such as rice, with nitrogen-fixing organisms.

The use of the growth and development bio-stimulants influenced the chemical composition of the garlic, but the effect was modified by the course of weather in different years of the research and also differs in individual edible organ. On average for years and organs all bio-stimulants increased the level of protein, minerals expressed as ash and enhanced antioxidant activity, whereas decreased the level of total carbohydrates. The most valuable edible organ proved to be the leaves of the garlic, which contained the most protein, fats, and minerals expressed as ash, were the richest source of fibre, vitamin $\mathrm{C}$ and polyphenols, and had the highest antioxidant activity of all the organs tested (Jedrszczyk et al., 2019).

The best results were obtained from forage products but cereals and potatoes showed a good reaction to phosphor as well. Nitroxin contains a set of the most effective bacteria including Azotobacter spirillum (Azospirillum) which causes the growth and development of the roots and aerial parts of the plants (Gimdil et al., 2013). The present study was carried out to protect the wild shallot in a natural habitat threatened by excessive harvesting and to find an appropriate cultivation method to produce more shallot. One of the best ways to stimulate growth is to provide optimal nutrition and use of bio-fertilizers. In this study, nutrition with bio-fertilizers and sulfur was used to improve the production of shallot because limited published data are available in this regard. 


\section{Materials and Methods}

\section{Experimental site properties}

The present study evaluated the effect of different treatments of bio- and chemical fertilizers on the qualitative and quantitative yield of the wild ecotype of shallot. The wild ecotype was cultivated through agricultural methods and the effect of different nutritional treatment was investigated on this ecotype, followed by comparing its yield with the yield and its components in the natural area. The experiment was conducted in the cold climatic conditions of Lorestan (Alashtar region), Iran during 2017-2019. The farm is located at $8 \mathrm{~km}$ of the city of Alashtar $\left(48^{\circ} 15^{\prime} 14^{\prime \prime} \mathrm{E}\right.$ and $\left.33^{\circ} 49^{\prime} 21^{\prime \prime} \mathrm{N}\right)$. The altitude is $1567 \mathrm{~m}$ above the sea level and the area has semi-cold and semi-humid climate. Rainfall distribution is from mid-October to mid-May and the average rainfall is $400-450 \mathrm{~mm}$. The average annual temperature is between 18 and $21^{\circ} \mathrm{C}$ (Table 1). Natural habitat is located in geographical coordinate $48^{\circ} 21^{\prime} 29^{\prime \prime} \mathrm{E}$ and $33^{\circ} 43^{\prime} 40^{\prime \prime} \mathrm{N}$ and the altitude is $2300 \mathrm{~m}$ above the sea level (Figure 1).

Table 1. Climatic information of Alashtar station (2017-2019)

\begin{tabular}{|c|c|c|c|c|c|c|}
\hline Month & $\begin{array}{c}\text { Temperature } \\
2017-2018 \\
\left({ }^{\circ} \mathrm{C}\right)\end{array}$ & $\begin{array}{c}\text { Temperature } \\
2018-2019 \\
\left({ }^{\circ} \mathrm{C}\right)\end{array}$ & $\begin{array}{c}\text { Temperature } \\
\text { Long-term } \\
\left({ }^{\circ} \mathrm{C}\right)\end{array}$ & $\begin{array}{c}\text { Rainfall } \\
2017-2018 \\
(\mathrm{~mm})\end{array}$ & $\begin{array}{c}\text { Rainfall } \\
2018-2019 \\
(\mathrm{~mm})\end{array}$ & $\begin{array}{c}\text { Rainfall } \\
\text { Long-term } \\
(\mathrm{mm})\end{array}$ \\
\hline November & 2.5 & 6.1 & 10.45 & 42 & 127.3 & 66.7 \\
\hline December & 4.5 & 3.3 & 5.25 & 52 & 124.1 & 66.4 \\
\hline January & 2.5 & 3.5 & 2.1 & 74 & 128.3 & 53.2 \\
\hline February & 3.6 & 4 & 2.1 & 50 & 102.5 & 84.0 \\
\hline March & 6.7 & 6.8 & 6.4 & 62 & 285.3 & 55.4 \\
\hline April & 10.9 & 10.0 & 9.45 & 70 & 0.0 & 73.0 \\
\hline Total & - & - & - & 350 & 767.5 & 398.7 \\
\hline
\end{tabular}

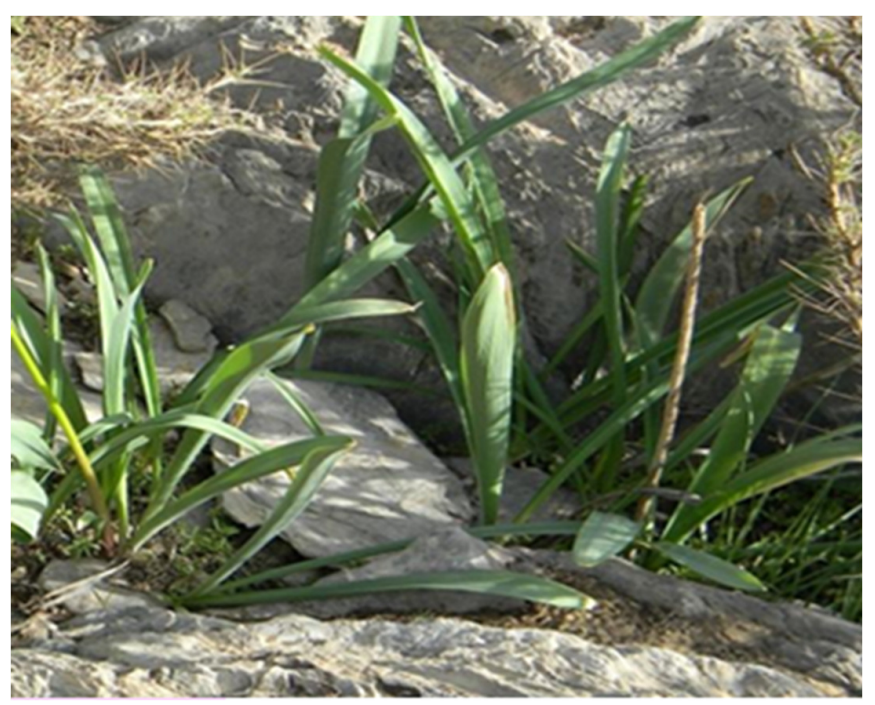

Figure 1. Wild shallot grown in a natural habitat

\section{Soil sampling}

The soil samples from twelve points of the field were collected from a depth of $0-20 \mathrm{~cm}$ and then were thoroughly mixed to obtain a sample of $500 \mathrm{~g}$. The analysis was conducted for major nutrients such as nitrogen, phosphorus, potassium, calcium, magnesium, $\mathrm{pH}$, and the soil type was adequately described in terms of soil physicochemical properties (Tables 2 and 3 ). 
Table 2. Physicochemical properties of the soil of the studied sites

\begin{tabular}{|c|c|c|c|c|c|c|c|}
\hline & $\begin{array}{c}\mathrm{K} \\
(\mathrm{mg} \mathrm{kg}-1)\end{array}$ & $\begin{array}{c}\mathrm{P} \\
(\mathrm{mg} \mathrm{kg}-1)\end{array}$ & $\begin{array}{c}\text { Total N } \\
(\%)\end{array}$ & $\begin{array}{c}\text { Organic } \\
\text { carbon }(\%)\end{array}$ & $\mathrm{pH}$ & $\begin{array}{c}\mathrm{EC} \\
(\mathrm{dS} \mathrm{m}-1)\end{array}$ & Texture \\
\hline Soil farm & 58 & 17 & 0.93 & 0.73 & 7.8 & 2.0 & Loam clay \\
\hline $\begin{array}{c}\text { Soil of natural habitat } \\
\text { of shallot }\end{array}$ & 46 & 12 & 0.64 & 0.21 & 6.7 & 1.6 & Loam sand \\
\hline
\end{tabular}

Table 3. Population of the total number of bacteria and fungi, number of phosphate solubilizing bacteria, number of N-stabilizing bacteria and phosphate solubilizing fungi per gram of soil in the farm and Natural habitat soil

\begin{tabular}{|c|c|c|c|c|c|c|c|}
\hline Soil & $\begin{array}{c}\text { Phosphate } \\
\text { solubilizing } \\
\text { fungi*/total } \\
\text { fungus } \%\end{array}$ & $\begin{array}{c}\text { Phosphate } \\
\text { solubilizing and } \\
\text { nitrogen } \\
\text { stabilizer*/Total\% }\end{array}$ & $\begin{array}{c}\text { Phosphate } \\
\text { solubilizing } \\
\text { fungi* }\end{array}$ & $\begin{array}{c}\text { Free } \\
\text { bacteria } \\
\mathrm{N} \\
\text { stabilizer* }\end{array}$ & $\begin{array}{c}\text { Phosphate } \\
\text { solubilizing } \\
\text { bacteria* }^{*}\end{array}$ & $\begin{array}{c}\text { Total* } \\
\text { fungus }\end{array}$ & $\begin{array}{c}\text { Total* }^{*} \\
\text { bacteria }^{*}\end{array}$ \\
\hline Farm soil & 11.4 & 7.2 & 24 & 9 & $5 \times 10^{2}$ & 210 & $7 \times 10^{3}$ \\
\hline $\begin{array}{c}\text { Soil of } \\
\text { natural } \\
\text { habitat of } \\
\text { shallot }\end{array}$ & 29.8 & 19.3 & 85 & 39 & $29 \times 10^{2}$ & 285 & $1.5 \times 10^{4}$ \\
\hline
\end{tabular}

${ }^{*}$ Number of bacteria or fungi per gram of soil

\section{Experimental material and treatments}

Using a randomized complete block design, the study was performed on shallot cultivation by three replications of eight treatments included nitroxin bio-fertilizer $(\mathrm{N})$, phosphate bio-fertilizer (B), sulfurchemical fertilizer $(S)$, combination of nitroxin bio-fertilizer + phosphate bio-fertilizer (NB), combination of nitroxin bio-fertilizer + sulfur-chemical fertilizer (NS), combination of phosphate bio-fertilizer and sulfurchemical fertilizer (BS), combination of nitroxin bio-fertilizer+ phosphate bio-fertilizer+ sulfur-chemical fertilizer (NBS), and control of wild ecotype which was cultivated without using any fertilizer (C). In this study, only one wild shallot ecotype was used. The bulbs were gathered from the natural habitat of the highlands near the study site.

The bulbs were planted in six rows and the distance between the rows was $30 \mathrm{~cm}$. The distance between the bulbs on a row was $10 \mathrm{~cm}$ and the cultivation depth of the bulbs was $15 \mathrm{~cm}$. Each block occupied an area of $20 \times 3 \mathrm{~m}^{2}$ including eight plots. The main experimental area had 24 plots since the treatments were replicated three times.

During the growing season, pest control and cultivation steps were performed on a routine basis and sampling was performed in three stages. The growth period in the natural habitat is from the first of April to the first of June and the growth period in the experimental site is from the first of March to the end of June; From each sampling plot, the two outer rows were regarded as the edge effect and the samples were taken from the four inner rows (Figure 2). Further, the data were obtained from 12 selected plants. Six points with a total area of $4 \mathrm{~m}^{2}$ were selected for sampling from the studied natural resource area. In natural habitats, the random throwing method was further utilized to measure the quantitative and qualitative traits of wild shallot and then to compare them with experimental plots.

\section{Data collection}

The parameters under study including plant height, bulb diameter, bulb dry weight, biological yield, and qualitative traits including allicin content, values of crude protein, potassium, and phosphor in $100 \mathrm{~g}$ of powdered bulbs of different treatments and natural area were compared with the best treatment. The data were collected from 12 plants that were selected from four inner rows. The measured parameters were as follows:

Plant height: The plant height was measured just before the leaf fall and from the ground level up to the highest leaf using a standard ruler. 
Bulb diameter: The diameter of the bulbs was recorded at the right angle to the longitudinal axis at the widest circumference of the bulb using a Vernier caliper.

Bulb dry weight: After harvesting, the leaves and roots were carefully cut and isolated, followed by placing the bulbs in a dryer at $80^{\circ} \mathrm{C}$ for $1 \mathrm{~h}$. Then, the weigh was converted to $\mathrm{kg} / \mathrm{ha}$ by a digital scale in order to estimate the yield.

Biological yield: After harvesting, the leaves, roots, and bulbs were placed in a dryer at $80^{\circ} \mathrm{C}$ for $1 \mathrm{~h}$ and the weight was converted to $\mathrm{kg} / \mathrm{ha}$ using an electronic weighing scale in order to estimate biological yield.

Allicin content: Totally, $100 \mathrm{~g}$ of powder was selected for essence extraction in order to prepare the standard solution. In addition, Valeman gel containing $80 \%$ allicin allyl propyl sulfide was used to extract diallyl disulfide. Two cases of the extract were washed in the mortar and $25 \mathrm{ml}$ of dichloromethane was added, followed by adding dry sodium sulfate to this mixture to remove water. Finally, $20 \mathrm{ml}$ of the solution was injected into the apparatus (Rahim and Hussain, 2011).

Specifications of the device used to measure the of allicin content: To measure allicin samples prepared by the HPLC, Shimadzu's HPLC system, Prominence series, consisting of a Bishoff pump, column 18C6/4 × $150 \mathrm{~mm}$ with a spectrophotometer system was used based on the internal standard of butyl-para-hydro benzoate and the method described by the British Academy of Sciences.

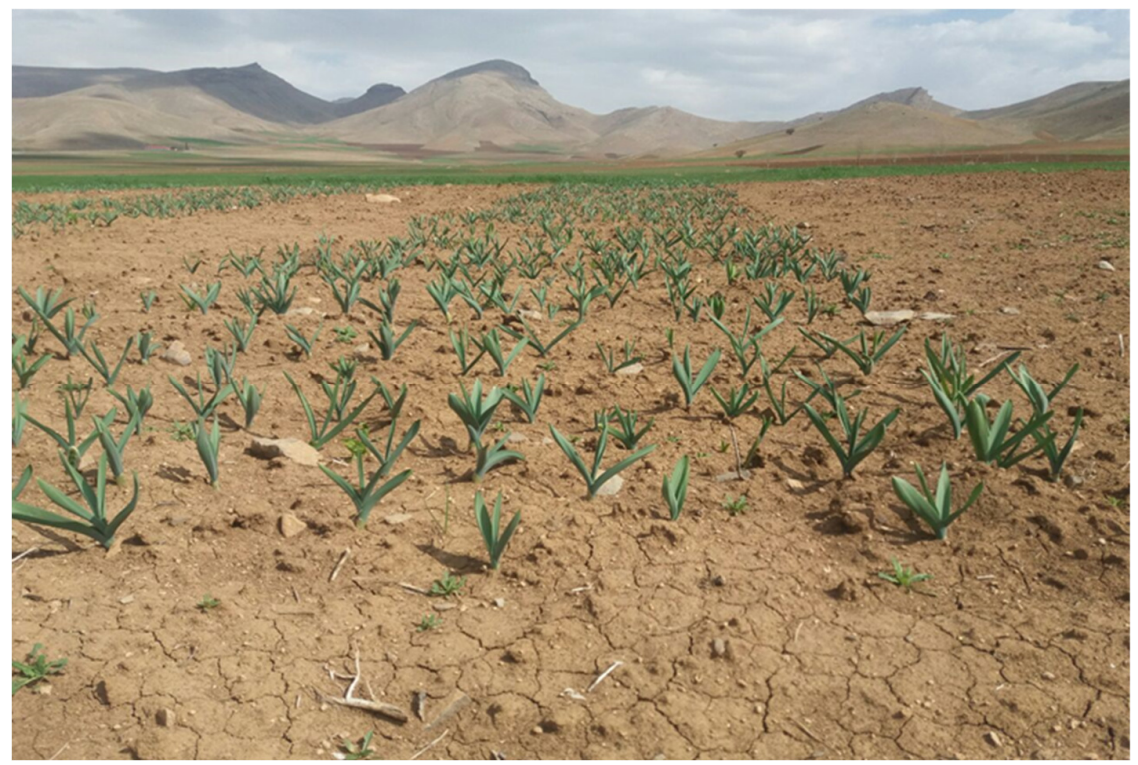

Figure 2. Planting of wild shallot in agricultural lands in the form of completely randomized block design

\section{Data analysis}

The data were subjected to analysis of variance (ANOVA) using MSTAT-C software. When the ANOVA showed significant differences, mean comparison was carried out using Duncan's multiple range test at $1 \%$ probability levels of significance. The correlations between parameters were done if applicable.

\section{Results and Discussion}

\section{Bulb dry weight}

The results showed a significant effect of fertilizer treatments on the dry weight of the shallot bulb $(\mathrm{p}<$ 0.01) (Table 4). The combination of nitroxin bio-fertilizer + sulfate chemical fertilizer (NS), as well as phosphate fertilizer treatment (B) had the highest $\left(827.83 \mathrm{~g} / \mathrm{m}^{2}\right)$ and lowest $\left(271 \mathrm{~g} / \mathrm{m}^{2}\right)$ bulb dry weight in the 
agricultural land, respectively (Table 5). The average bulb dry weight in the natural area was $130 \mathrm{~g} / \mathrm{m}^{2}$ (Table 6).

Kaykha et al. (2014) reported similar results in this regard. They studied the effect of bio-fertilizers on the garlic bulb yield and obtained the highest and lowest yields of garlic bulb using nitroxin bio-fertilizer at $9744 \mathrm{~kg} / \mathrm{ha}$ and phosphate bio-fertilizer at $8196 \mathrm{~kg} / \mathrm{ha}$, respectively. In addition, Shah Saud et al. (2013) found that sulfur increases the uptake of $N, P, K$, and $S$ by the plant, which might lead to enhanced synthesis and tissue translocation to the bulbs and thus increase the total yield. Further, Pradhan et al. (2014) reported the effect of sulfur on nitrogen uptake by the plant. They also demonstrated that higher levels of sulfur influenced the nitrogen uptake of the plant which may have affected the synthesis and translocation of the stored materials.

Likewise, other researchers such as Shafeek et al. (2013) confirmed the increased uptake of nitrogen due to higher doses of potassium consumption. It seems that the field cultivation provides favorable climatic conditions (e.g., temperature and humidity) for the wild ecotype of the plant. Desirable conditions cause differences in the yield and growth between farm ecotype and natural ecotype of wild shallot (Figure 3). The availability of sufficient moisture and the favorable temperature conditions along with the presence of sufficient nutrients in agricultural lands have increased the yield of wild shallot planted in agricultural lands, while in natural areas, the restriction of access to growth factors such as moisture and nutrients leads to low yields.

Table 4. Analysis of variance (mean square) of the shallot traits under different fertilizers

\begin{tabular}{|c|c|c|c|c|c|c|}
\hline Sources of vitiation & DF & $\begin{array}{c}\text { Biological } \\
\text { yield }\end{array}$ & $\begin{array}{c}\text { Plant } \\
\text { height }\end{array}$ & Allicin & $\begin{array}{c}\text { Dry } \\
\text { weight }\end{array}$ & $\begin{array}{c}\text { Bulb } \\
\text { diameter }\end{array}$ \\
\hline Year & 1 & $67.4^{\text {ns }}$ & $101.7^{\text {ns }}$ & $0.01^{\text {ns }}$ & $52.0^{\text {ns }}$ & $3.63^{\text {ns }}$ \\
\hline Error & 4 & 6918.4 & 3.56 & 0.018 & 52.0 & 0.240 \\
\hline Fertilizer treatments & 7 & $177095^{* *}$ & $113.15^{* *}$ & $0.56^{* *}$ & $183807.6^{* *}$ & $1.249^{* *}$ \\
\hline Fertilizer treatments*year & 7 & $0.09^{\text {ns }}$ & $0.185^{\text {ns }}$ & $0.005^{\text {ns }}$ & $0.22^{\text {ns }}$ & $0.020^{\text {ns }}$ \\
\hline Total error & 28 & 1551.1 & 3.90 & 0.009 & 1505.6 & 0.16994 \\
\hline CV\% & & 8.7 & 3.1 & 8.9 & 9.4 & 8.1 \\
\hline
\end{tabular}

NS and ${ }^{* *}$ : non-significant and significant at $1 \%$ probability levels, respectively.

Table 5. Comparison of some traits of wild shallot cultivated in agricultural land and influenced by chemical and bio-fertilizers

\begin{tabular}{|c|c|c|c|c|c|}
\hline Treatment & $\begin{array}{c}\text { Allicin } \\
(\%)\end{array}$ & $\begin{array}{c}\text { Bulb diameter } \\
(\mathrm{cm})\end{array}$ & $\begin{array}{c}\text { Dry tuber weight } \\
\left(\mathrm{g} \mathrm{m}^{-2}\right)\end{array}$ & $\begin{array}{c}\text { Plant height } \\
(\mathrm{cm})\end{array}$ & $\begin{array}{c}\text { Biological yield } \\
\left(\mathrm{g} \mathrm{m}^{-2}\right)\end{array}$ \\
\hline S & $1 \mathrm{c}$ & $5.3 \mathrm{~b}$ & $384.3 \mathrm{bc}$ & $57.2 \mathrm{c}$ & $421.82 \mathrm{bc}$ \\
\hline $\mathrm{N}$ & $0.89 \mathrm{~d}$ & $4.9 \mathrm{bc}$ & $324.17 \mathrm{~d}$ & $61.6 \mathrm{bc}$ & $364.2 \mathrm{de}$ \\
\hline $\mathrm{B}$ & $0.85 \mathrm{~d}$ & $4.7 \mathrm{c}$ & $271 \mathrm{e}$ & $59.1 \mathrm{c}$ & $320 \mathrm{e}$ \\
\hline $\mathrm{NB}$ & $1.005 \mathrm{c}$ & $4.58 \mathrm{c}$ & $392.3 \mathrm{bc}$ & $62.8 \mathrm{~b}$ & $431 \mathrm{bc}$ \\
\hline NS & $1.09 \mathrm{bc}$ & $6.1 \mathrm{a}$ & $827.83 \mathrm{a}$ & $73.4 \mathrm{a}$ & $861.2 \mathrm{a}$ \\
\hline BS & $1.16 \mathrm{~b}$ & $4.88 \mathrm{bc}$ & $348 \mathrm{dc}$ & $62.8 \mathrm{~b}$ & $388.35 \mathrm{dc}$ \\
\hline NBS & $1.76 \mathrm{a}$ & $5.25 \mathrm{~b}$ & $422 \mathrm{~b}$ & $61.6 \mathrm{~b}$ & $428.2 \mathrm{~b}$ \\
\hline C & $0.79 \mathrm{~d}$ & $4.81 \mathrm{bc}$ & $319.3 \mathrm{~d}$ & $61.1 \mathrm{bc}$ & $360.18 \mathrm{de}$ \\
\hline
\end{tabular}

Mean separation within columns by Duncan's multiple range test at $1 \%$ probability level. Means followed by the same letter in a column within a treatment are not significantly different. In this Table $S=$ sulfur fertilizer, $N=N$ itroxin, $B$ $=$ Phosphate $2, \mathrm{NB}=$ combination of Nitroxin + Phosphate $2, \mathrm{NS}=$ Nitroxin + sulfur fertilizer, $\mathrm{BS}=$ combination of Phosphate $2+$ sulfur fertilizer, NBS $=$ combination of Nitroxin + Phosphate $2+$ sulfur fertilizer and $\mathrm{C}=$ control treatment (wild bulbs shallot without fertilizer) 
Table 6. Comparison of the control and superior treatment in the field with that of wild shallot in the natural habitat

\begin{tabular}{|c|c|c|c|c|c|c|c|c|}
\hline Treatment & $\begin{array}{c}\text { Allicin } \\
(\%)\end{array}$ & $\begin{array}{c}\mathrm{P}^{*} \\
(\mathrm{mg})\end{array}$ & $\begin{array}{c}\mathrm{K}^{*} \\
(\mathrm{mg})\end{array}$ & $\begin{array}{c}\text { Crude* } \\
\text { protein } \\
(\mathrm{mg})\end{array}$ & $\begin{array}{c}\text { Dry } \\
\text { weight } \\
\left(\mathrm{g} \mathrm{m}^{-2}\right)\end{array}$ & $\begin{array}{c}\text { Biological } \\
\text { yield } \\
\left(\mathrm{g} \mathrm{m}^{-2}\right)\end{array}$ & $\begin{array}{c}\text { Plant } \\
\text { height } \\
(\mathrm{cm})\end{array}$ & $\begin{array}{c}\text { Bulb } \\
\text { diameter } \\
(\mathrm{cm})\end{array}$ \\
\hline $\begin{array}{c}\text { Superior treatment } \\
\text { (farmed ecotype })\end{array}$ & $1.7 \mathrm{a}$ & $101 \mathrm{a}$ & $580 \mathrm{a}$ & $270 \mathrm{a}$ & $827 \mathrm{a}$ & $862.2 \mathrm{a}$ & $71.8 \mathrm{a}$ & $5.7 \mathrm{a}$ \\
\hline $\begin{array}{c}\text { Wild ecotype } \\
\text { (study in natural) }\end{array}$ & $0.84 \mathrm{~b}$ & $64 \mathrm{c}$ & $311 \mathrm{c}$ & $123 \mathrm{c}$ & $130 \mathrm{c}$ & $170 \mathrm{c}$ & $42 \mathrm{c}$ & $3.1 \mathrm{c}$ \\
\hline $\begin{array}{c}\text { Control } \\
\text { (without fertilizer) }\end{array}$ & $0.75 \mathrm{c}$ & $84 \mathrm{~b}$ & $510 \mathrm{~b}$ & $210 \mathrm{~b}$ & $318.3 \mathrm{~b}$ & $402 \mathrm{~b}$ & $59.6 \mathrm{~b}$ & $4.56 \mathrm{~b}$ \\
\hline
\end{tabular}

${ }^{*}$ Per 100 gr of dried bulb wild shallot powder

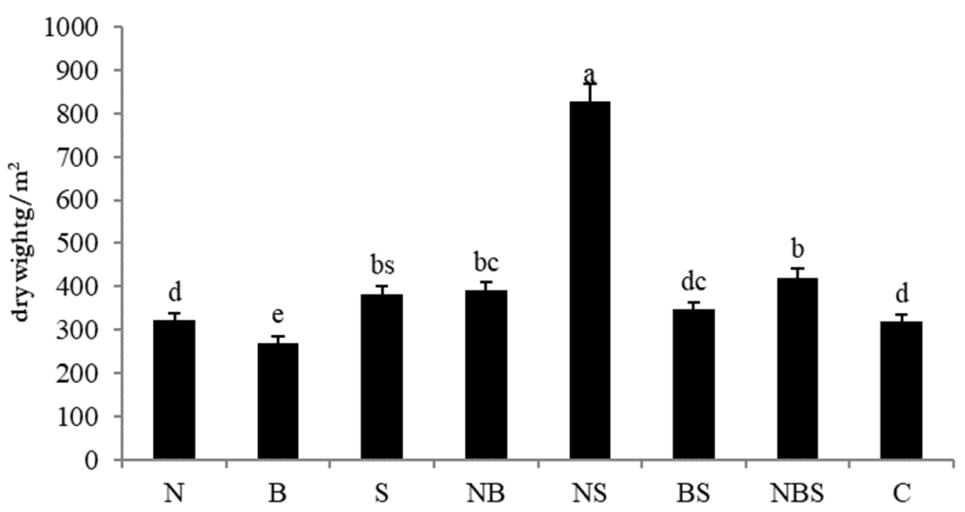

Figure 3. Comparison of the average dry weight under various biological and chemical fertilizer treatments Mean separation within columns by Duncan's multiple range test at $(\mathrm{p}<0.01)$ probability level.

$S=$ sulfur fertilizer, $\mathrm{N}=$ Nitroxin, $\mathrm{B}=$ Phosphate $2, \mathrm{NB}=$ combination of Nitroxin + Phosphate $2, \mathrm{NS}=$ Nitroxin + sulfur fertilizer, BS = combination of Phosphate $2+$ sulfur fertilizer, NBS =combination of Nitroxin + Phosphate $2+$ sulfur fertilizer and $\mathrm{C}=$ control treatment (wild bulbs shallot without fertilizer)

Vertical bars indicate standard deviations. Similar letter(s) are not significantly different at 5\% probability level, using Duncan's multiple range test.

\section{Bulb diameter}

The results revealed a significant difference between fertilizer treatments in terms of the effect on the bulb diameter of shallot $(\mathrm{p}<0.05)$ (Table 4). The combination of nitroxin + sulfur $(\mathrm{NS})$ had the highest bulb diameter $(5.7 \mathrm{~cm})$ while the combination of phosphate and nitroxin (BS) had the lowest bulb diameter ( 4.3 $\mathrm{cm}$ ) (Table 5). Moreover, bulb diameter of the above-mentioned ecotype that wildly grows in nature equals 3.1 $\mathrm{cm}$ (Table 6) which is in line with the results of Farooqui et al. (2009). Also, Girigowda (2005) demonstrated an increase in the yield and growth of the bulb diameter by adding nitrogen and sulfur. Sulfur is considered an essential nutrient and its role in balanced nutrition and thus crop production is becoming increasingly prominent. It performs many physiological functions such as sulfur and methionine synthesis.

Additionally, methionine can be one of the initiators of protein synthesis in the plant and the formation of tissues and dry matter (Brosnan and Brosnan, 2006). The results indicated that the minimum bulb diameter of the treatments in the experiment was greater compared to that of the bulb in the natural area. It seems that good growth conditions are provided for the wild ecotype of the plant on the farm by plowing. Soil texture is further made up of sand and gravel in dense mountainous soil in which there is a greater amount of compaction between the particles. These conditions, along with other conditions can decrease the bulb diameter of shallot. 


\section{Plant height}

Based on the results, a significant difference was observed between fertilizers regarding the effect on the height of shallot $(\mathrm{p}<0.01)$ (Table 4). The combination of nitroxin + sulfur (NS) indicated the highest plant height $(71.7 \mathrm{~cm})$ while the phosphate fertilizer $(B)$ demonstrated the lowest plant height $(65.65 \mathrm{~cm})$ (Table 5). The height of the shallot in the studied natural habitat was $42 \mathrm{~cm}$ (Table 6). In another study, Namakka et al. (2014) reported that nitrogen and sulfur increased the plant efficiency and height in the Alliaceae family. The reaction of the plant to nitrogen as an essential ingredient for the growth relies on different factors such as soil conditions, plant species, nutrient levels, and interactions between the elements of the soil. Having a photosynthetic surface is more effective in increasing height and yield. In addition, it seems that sulfur plays a vital role in nitrogen efficiency. The height of cultivated shallot in the farm was higher than that of wild shallots. Further, there is a high competition between plant species regarding absorbing nutrients in natural resources due to limited resources (Table 6).

\section{Biological yield}

The results demonstrated that there was a significant difference between different levels of fertilizers in terms of their effect on the biological yield of shallot at $\mathrm{p}<0.01$ probability level (Table 4 ). The combination of nitroxin + sulfur (NS) and phosphate fertilizer (B) had the highest $\left(2.862 \mathrm{~g} / \mathrm{m}^{2}\right)$ and the lowest $\left(320 \mathrm{~g} / \mathrm{m}^{2}\right)$ biological yield, respectively (Table 5). The average biological yield of the bulbs in the studied natural area was $170 \mathrm{~g} / \mathrm{m}^{2}$ (Table 6). Hamda et al. (2012) found that conditions for nitrogen absorption are associated with other factors by considering the role of nitroxin in increasing the biological yield of the plants. Furthermore, it seems that, increasing plant leaf area, along with photosynthetic tissues improves the biological yield of the plants. Bio-fertilizers as microbial enzymes are typically able to convert soil nutrients from the inaccessible to the accessible state through biological processes, leading to the plant growth and the interaction between nutrients and their absorption in the soil (Table 6).

\section{Allicin percent}

Based on the results, fertilizer treatment had a significant effect on the allicin percent of shallot (Table 4). The combination of nitroxin + sulfur + phosphate (NBS) showed the highest allicin percent (1.7). However, the lowest allicin (0.75) was observed for the control (C) (Table 5). The average amount of allicin percent in the studied natural areas was $84 \%$ (Table 6).

Singh et al. (2012) reported similar results in this regard. They concluded that the availability of sulfur and nitroxin effectively improved the level of allicin in the Alliaceae family. Similarly, Bloem et al. (2005) indicated that the amount of allicin strongly relied on the distance between the rows with a maximum amount at the $30 \mathrm{~cm}$ row distance. Furthermore, it seems that, the amount of allicin in the treated shallots was higher than that of the shallots in the natural habitat. This is due to the presence of allicin constituents and nutrients in agricultural fields. The amount of available sulfur for shallots planted in agricultural lands has increased the amount of allicin in the bulbs produced in agricultural lands, while there is limited access to sulfur in natural resources (Table 6).

\section{Crude protein, potassium, and phosphor}

The effective amounts of crude protein, potassium, and phosphor in $100 \mathrm{~g}$ of the powdered bulb of control treatment were compared with bulbs of the natural area and the bulbs of the best treatment in terms of the bulb dry weight (NS). The results showed that the amount of these traits in three treatments was 210,123, and $270 \mathrm{mg}$ for crude protein, 510, 311, and $580 \mathrm{mg}$ for potassium, as well as 84,64 , and $101 \mathrm{mg}$ for phosphorus, respectively (Table 6).

Furthermore, it seems that, the presence of different bio-chemical fertilizers in the farm improves the interaction between the elements. Also, nitrogen absorption is positively related to sulfur, potassium, and 
phosphorus. On the other hand, sulfur and potassium have a positive interaction effect regarding absorbing each other. Also, sulfur increases nitrogen productivity in plants.

\section{Correlation coefficients}

The correlation coefficient results (Table 7) indicated that there was a direct correlation between the measured traits. In addition to, the calculation of the correlation coefficients showed that the highest correlation belonged to biological yield with the bulb dry weight with $r=99 \%$. Also, a correlation was observed between the height and biological yield $(\mathrm{r}=86 \%)$, as well as the diameter of the bulb and the height of the plant $(\mathrm{r}=67 \%)$. In this study, no correlation was observed between quantitative traits (yield and yield components) and allicin percent. Also, in shallot Sood et al. (2000) showed the lack of significant correlation between quantitative and qualitative traits.

Table 7. Simple correlation coefficients of studied traits (Type of correlation is second-degree equation)

\begin{tabular}{|c|c|c|c|c|c|}
\hline & Dry weight & Biological yield & Plant height & Allicin & $\begin{array}{c}\text { Bulb } \\
\text { diameter }\end{array}$ \\
\hline Dry weight & 1 & & & & \\
\hline Biological yield & $0.998^{*}$ & 1 & & & \\
\hline Plant height & $0.863^{*}$ & $0.862^{*}$ & 1 & & \\
\hline Allicin & $0.16 \mathrm{~ns}$ & $0.16 \mathrm{~ns}$ & $0.08 \mathrm{~ns}$ & 1 & 1 \\
\hline Bulb diameter & $0.55^{*}$ & $0.547^{*}$ & $0.67^{*}$ & $0.29 \mathrm{~ns}$ & 1 \\
\hline
\end{tabular}

NS and ${ }^{*}$ : non-significant and significant at $(\mathrm{p}<0.01)$ probability levels, respectively.

\section{Regression analysis}

Regression analysis is used to examine the effect quantitative characteristics on other traits (Cox, 1979). In this study, the regression analysis was used for the relationship of the bulb diameter to the bulb dry weight, as well as the plant height with biological yield and bulb dry weight with biological yield. Based on this analysis, the reaction of dry weight to biological yield, as well as plant height to the biological yield and bulb dry weight to biological yield of the bulbs was described with a linear curve and a straight-line equation (Figures 4 and 5). The positive regression between bulb dry weight and biological yield and biological yield with plant height is a logical relationship because the plant produces tissue by photosynthesis. The higher the amount of tissue produced (biological yield) the higher the yield of the dry weight produced by the bulb and the height of the plant. Furthermore, the positive regression between plant height and production diameter of the plant is a logical relationship because the higher the plant height, the higher the number of photosynthetic branches of the plant, so the production and storage of the product is higher than photosynthesis, so the diameter of the bulbs increases. 
Kakolvand E et al. (2020). Not Bot Horti Agrobo 48(4):2215-2227

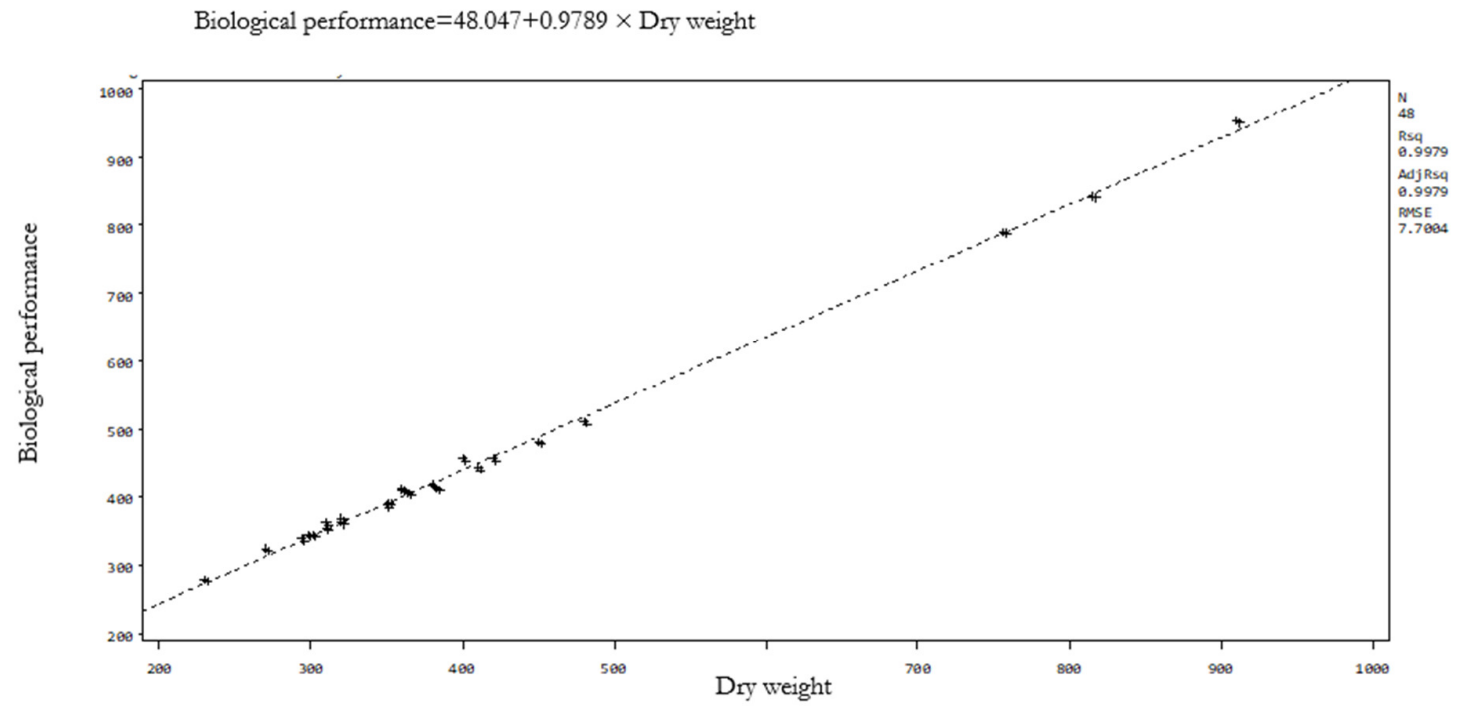

Figure 4. Regression between dry weight of bulbs and biological yield influenced by biological and chemical fertilizers

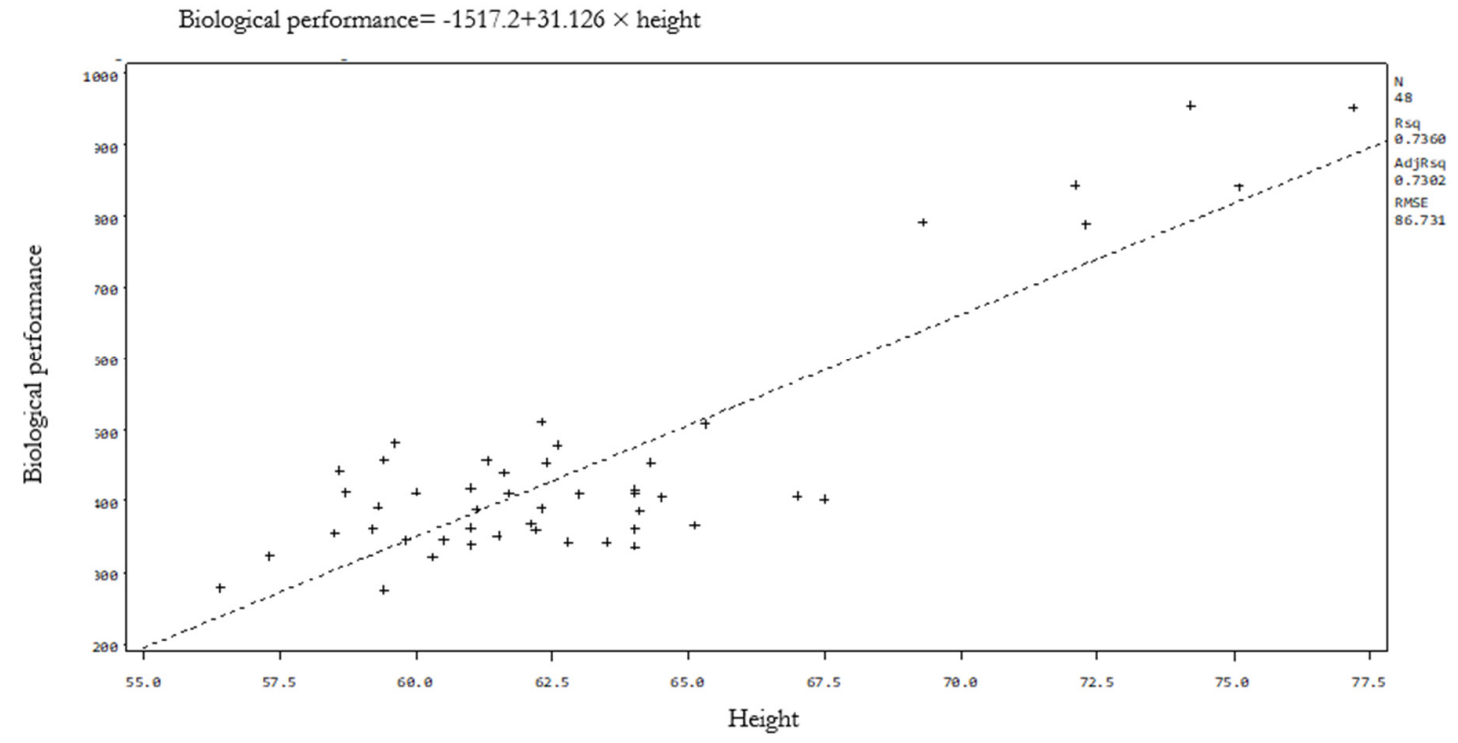

Figure 5. Regression between height and biological yield influenced by biological and chemical fertilizers 


\section{Conclusions}

The results revealed that shallot can be cultivated on the farm to prevent the destruction of the plant. This plant is subject to destruction due to its excessive use, as well as the increased need and the excessive use of its active ingredients in food and pharmaceutical industries in recent years. The wild ecotype of this plant was cultivated on the farm using biological fertilizer. The combination of nitroxin $+\operatorname{sulfur}(\mathrm{NS})$ showed the highest values of traits such as dry bulb weight, biological yield, plant height and bulb diameter. In addition to, NBS treatment was more desirable in terms of the active ingredient of allicin compared to the other treatments and natural habitat. The effective amounts of crude protein, potassium and phosphorus produced by the bulbs of shallot produced in agricultural lands were higher than the amount of these substances in the bulbs of shallot in natural habitat.

The differences were improved more than three times when comparing the measured traits between the wild and cultivated ecotypes regarding the measured traits so that the lowest recorded traits in the cultivated ecotype on the farm were higher than the recorded average in the natural area. The production of these species in agricultural systems can serve as an essential strategy for supplying the growing market of these plants. Therefore, the development and extension of its farming method can lead to the sustainable production of shallot and conservation of its natural habitat diversity. Considering the growing demand for this product and its market value, it seems to be suitable for farmers. On the other hand, its cultivation can be considered as an approach for reducing the pressure on natural areas. However, making better decisions in this area depends on further research in this regard.

\section{Authors' Contributions}

Conceptualization, Data curation, Funding acquisition, Writing - original draft, Writing Investigation and Methodology: EK; Project administration and Supervision, Validation, Resources and Visualization, editing: KA; Software: AE; Formal analysis: MA; All authors read and approved the final manuscript.

\section{Acknowledgements}

This research received no specific grant from any funding agency in the public, commercial, or not-forprofit sectors.

\section{Conflict of Interests}

The authors declare that there are no conflicts of interest related to this article.

\section{References}

Beato VM, Orgaz F, Mansilla F, Montaño A (2010). Changes in phenolic compounds in garlic (Allium sativum L.) owing to the cultivar and location of growth. Journal of Plant Foods for Human Nutrition 66(3):218-223. https://doi.org/10.1007/s11130-011-0236-2

Bloem E, Haneklaus S, Schnug E (2005). Influence of nitrogen and sulfur fertilization on the allicin content of onions and garlic. Journal of Plant Nutrition 27(10):1827-1839. https://doi.org/10.1081/PLN-200026433 
Borde M, Dudhane M, Jite P (2009). Role of bioinoculant (AM Fungi) increasing in growth, flavor content and yield in Allium sativum L. under field condition. Notulae Botanicae Horti Agrobotanici Cluj-Napoca 37:124-128. https://doi.org/10.15835/nbha3723289

Brosnan JT, Brosnan ME (2006). The sulfur-containing amino acids: an overview. Journal of the National Library of Medicine 136:16365-16405. https://doi.org/10.1093/jn/136.6.1636S

Dogliotti S, García MC, Peluffo S, Dieste J, Pedemonte AJ, Bacigalupe GF, ... Rossing WAH (2014). Co-innovation of family farm systems. Journal of Agricultural Systems 126(2014):76-86. https://doi.org/10.1016/j.agsy.2013.02.009

Fang Sheng X, Yan He L (2006). Solubilization of potassium-bearing minerals by wild-type strain of Bacillus edaphicus and its mutants and increased potassium uptake by wheat. Canadian Journal of Microbiology 52(1):66-72. https://doi.org/10.1139/w05-117 PMID: 16541160

Farooqui MA, Naruka IS, Rathore SS, Singh PP, Shaktawat RPS (2009). Effect of nitrogen and sulfur levels on growth and yield of garlic (Allium sativum L.). Asian Journal of Food and Agro-Industry Special Issue:18-23.

Gimdil R, Shahgholi H, Ajiorloo AR, Shaban M (2013). Study on phenology stages of cultivated Persian shallot (Allium hirtifolium) in Mashhad region. International Journal of Farming and Allied Sciences 2:1223-1225.

Gitin L, Dinica R, Parnavel R (2012). The Influence of Extraction Method on the Apparent Content of Bioactive Compounds in Romanian Allium spp. leaves. Notulae Botanicae Horti Agrobotanici Cluj-Napoca 40(1):93-97. https://doi.org/10.15835/nbha4017212

Girigowda JR, Narasegowda NC, Krishna HC (2005). Effect of fertilizer levels on uptake of primary nutrients and bulb yield of onion hybrids. Mysore Journal of Agricultural Sciences 39(4):557-560.

Hamda El, Sayed AEl, Morsy AHA (2012). Response of productivity and storability of garlic (Allium sativum L.) to potassium levels and foliar spray with mepiquat chloride (PIX). International Research Journal of Agricultural and Soil Sciences 2(7):298-305.

Jedrszczyk E, Kopec A, Buckli P, Ambroszyki AM, Skoweras B (2019). The enhancing effect of plants growth biostimulants in garlic cultivation on the chemical composition and level of bioactive compounds in the garlic leaves, stems and bulbs. Notulae Botanicae Horti Agrobotanici Cluj-Napoca 47(1):81-91. https://doi.org/10.15835/nbha47111074

Kheirkhah M, Dadkhah A (2009). Study of Allium altissimum Regel phenology and consider how to domesticating it. Journal of Horticulture Researches in Pajouhesh \& Sazandegi 82:19-24.

Kopriva S, Buchert T, Fritz G (2002). The presence of an iron-sulfur cluster in adenosine, phosphosulfate reductase separates organisms utilizing adenosine 5'-phosphosulfate and phosphoadenosine 5'-phosphosulfate for sulfate assimilation. Journal of Biological Chemistry 227(24):21786-91.

Manuel Beato V, Orgaz Mansilla F, Montaño A (2011). Changes in phenolic compounds in garlic (Allium sativum L.) owing to the cultivar and location of growth. Journal of Plant Foods for Human Nutrition 66:218-223. https://doi.org/10.1007/s11130-011-0236-2

Namakka A, Nwokeocha OW, Ihuoma O (2014). Effect of phosphorus fertilizer on growth and yield of cowpea (Vigna unguiculata). Journal of Pharmacy and Biological Sciences 9:74-82. https://doi.org/10.9790/300809547482

Pradhan R, Pattnaik AK, Tripathy P, Mallikarjunarao K, Sahoo BB, Lenka J (2015). Influence of sulfur fertilization on nutrient uptake of onion (Allium cepa L). Journal of Crop and Weed 11(Special Issue):134-138.

Rahim MA, Hussain MA (2011). Effect of time of planting, mother bulb size and plant density on the yield of garlic. Bangladesh Journal of Agricultural Sciences 9:12-118.

Singh RK, Dubey BK, Bhonde SR, Gupta RP (2012). Correlation and path coefficient studies in garlic (Allium sativum L). Journal of Spices and Aromatic Crops 20(2):81-85.

Shafeek MR, Nagwa MK, Hassan SM, Singer, Nadia HM, Greadly EL (2013). Effect of potassium fertilizer and foliar spraying with etherel on plant development, yield and bulb quality of onion plants (Allium cepa L.). Journal of Applied Sciences and Research 9(2):1140-1146.

Shah S, Chun Y, Razaq M, Luqman M, Fahad Sh, Abdullah M, Sadiq A (2013). Growth, yield and bulb quality of onion plants (Allium cepa L.) as affected by foliar and soil application of potassium. Journal of Biology, Agriculture, and Healthcare 3(16):18-124.

Sood DR, Chokar V, Singh J (2000). Studies on growth, pungency and flavor characteristics of varieties of garlic (Allium sativum L.) bulbs during development. Journal of Vegetable Sciences 27(2):180-184. 
Tilman D, Balzer CH, Jason Hill J, Befort BL (2011). Global food demand and the sustainable intensification of agriculture. Proceedings of the National Academy of Sciences 108(50):20260-20264. https://doi.org/10.1073/pnas.1116437108

OPEN ACCESS

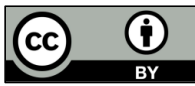

The journal offers free, immediate, and unrestricted access to peer-reviewed research and scholarly work. Users are allowed to read, download, copy, distribute, print, search, or link to the full texts of the articles, or use them for any other lawful purpose, without asking prior permission from the publisher or the author.

License - Articles published in Notulae Botanicae Horti Agrobotanici Cluj-Napoca are Open-Access, distributed under the terms and conditions of the Creative Commons Attribution (CC BY 4.0) License.

(c) Articles by the authors; UASVM, Cluj-Napoca, Romania. The journal allows the author(s) to hold the copyright/to retain publishing rights without restriction. 